\title{
SEEDLING GROWTH PERFORMANCE OF FOUR Syzygium species IN THE SIMULATED LIGHT AND SOIL NUTRIENT ENVIRONMENTS OF A RAIN FOREST IN SRI LANKA
}

\author{
H K Gamage1, B M P Singhakumara', P M S Ashton² \\ ${ }^{1}$ Department of Forestry and Environmental Science, University of Sri Jayewardenepura, \\ Nugegoda \\ ${ }^{2}$ School of Forestry and Environmental Studies, Yale University, New Haven, USA.
}

Seedlings of four species of Syzygium (S. firmum, S. makul, S. operculatum, $S$. rubicundum) were investigated for differences in growth and survival after one and half years growth in a nursery experiment. All four species co-exist in the moist evergreen rain forest of South western Sri Lanka. S. firmum is a canopy tree on valleys to midslopes. $S$. rubicundum is considered a canopy tree of late-successional forest on hill mid slops. Both $S$. makul and $S$. operculatum are sub canopy trecs of late-successional forest along streamways of lower slopes and valleys.

Seedlings of each species were grown within replicated light and soil nutrient treatments found in the groundstorey forest environments. The light treatments exposed seedlings to i) full sun; ii) sunlight like that at the center of a $200 \mathrm{~m}^{2}$ forest opening. iii) sunlight like that at the center of a $400 \mathrm{~m}^{2}$ canopy opening; iv) $50 \%$ shade of sunlight with quality similar to the outside edge of a $400 \mathrm{~m}^{2}$ canopy opening on the shaded side; v) $20 \%$ of sunlight with a quality similar to the inside edge of a $400 \mathrm{~m}^{2}$ canopy opening on the shaded side and vi) $1 \%$ of sunlight with a quality and amount similar to the forest understorey. Within each light treatment seedlings were grown with additions of phosphorus, potassium, magnesium, all three combined and a control with no additional nutrients. At the end of one and half years seedlings were measured for net photosynthesis, height increment, leaf number and survival.

Seedling survival for all species was low in the forest understorey treatment. Both survival and seedling height were greatest in shelters simulating forest openings. Leaf production was highest in full sun and inside edge light treatments and all species had their greatest net photosynthesis in the inside edge treatment. For nutrient treatments phosphorus promoted greatest seedling growth in all species.

Proceedings of the Third Annual Forestry Symposium 1997, of the Department of Forestry and Environmental Science, University of Sri Jayewardenepura, Sri Lanka 